\title{
Influence of kunapajala treatment from vrikshyaurveda on leaves of tomato (lycopersicon esculentum 1 . Cv. Selection 22) and its comparison with conventional farming and organic farming.
}

\author{
R. S. Deshmukh* N. N. A. Patil ${ }^{1}$ and T. D. Nikam ${ }^{2}$ \\ 1. Post Graduate Research Centre in Botany, Tuljaram Chaturchand College, Baramati 413102, \\ Dist. Pune (M.S.) India. Phone- 02112222988, \\ 2. Department of Botany; University of Pune, Pune. - 411007 (M.S.) India
}

\begin{abstract}
Kunapajala is a fermentation product of easily available ingredients and it works as a natural plant growth booster. The experiments were conducted using pot culture method for conventional farming, organic farming and kunapajala treatment in organic way. The results obtained under the kunapajala treatment were more effective for inducing number of leaves per plant and biomass of leaves compared to conventional farming and organic farming. The leaf area was same under both conventional farming and kunapajala treatment. The leaves showed highest relative water content $(R W C)$, osmotic potential (OP) of cell sap, total chlorophylls, chlorophyll stability index, carotenoids and xanthophylls and lowest percentage of membrane injury under kunapajala treatment followed by conventional farming and organic farming. Bioorganic study showed that kunapajala had upper hand, followed by organic farming and conventional farming in terms of soluble proteins, total carbohydrates, polyphenol, proline, glycine betain and ascorbic acid. The antioxidant property of tomato leaf was highest with kunapajala treatment compared to conventional farming and organic farming as revealed by activity of enzymes viz. catalase, peroxidase, polyphenol oxidase, IAA oxidase and super oxide dismutase. This overall picture shows that kunapajala treatment is superior to conventional farming and organic farming as it brings about physiological, biochemical and enzymatic enhancement in the leaves of tomato under organic farming conditions.
\end{abstract}

Keywords-Bio-organics, kunapajala, leaf, oxidative enzymes, organic farming, tomato.

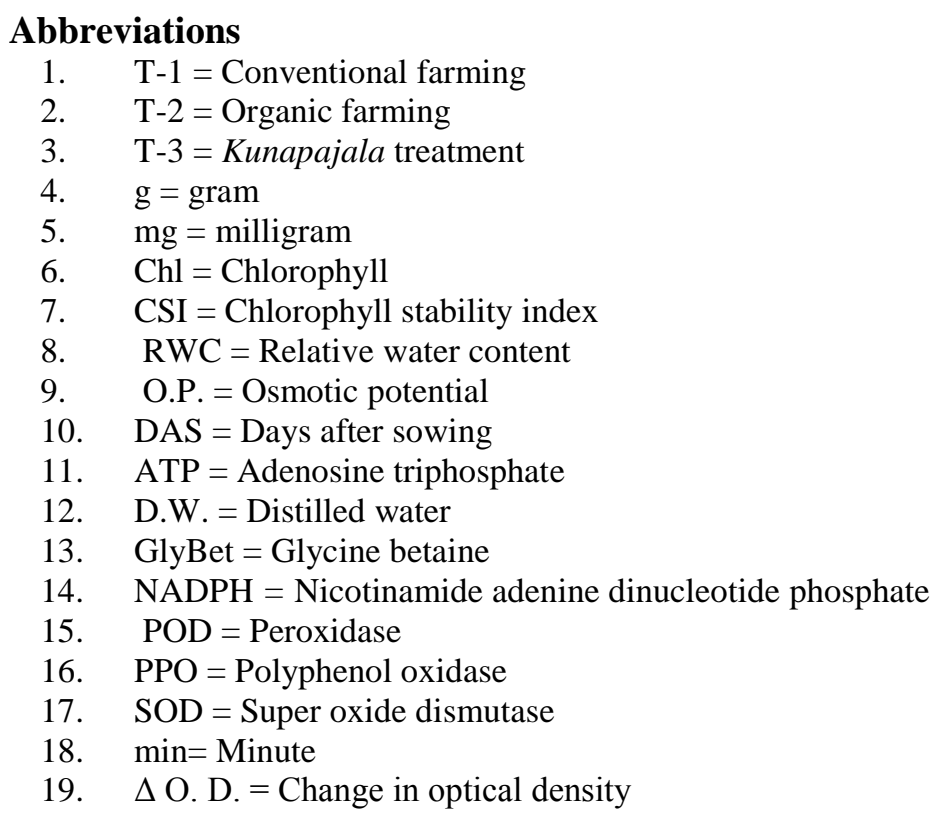




\section{INTRODUCTION}

The vegetables are important in human diet for their vitamin and mineral content essential for metabolic processes taking place within the human body. Tomato is solanaceous fruit vegetable available round the year. It is cultivated in tropics and subtropics of the world. It is believed that consumption of one tomato per day enhances the health status of individuals and it is considered to be important in diet as it is quite high in nutritive value ${ }^{1}$. Tomato is the top source of Vitamin A and C. It also contains a significant amount of dietary fibers, beta-carotene, iron, lycopene, magnesium, niacin, potassium, phosphorus, riboflavin and thiamine.

India has made spectacular breakthrough in production and consumption of fertilizers during the last four decades. But consumption of chemical fertilizers will be quite a limiting factor for increasing agriculture production in future. The cost of fertilizers has been enormously increasing to an extent that they are out of reach of the small and marginal farmers. It has become impractical to apply such costly inputs for a crop of marginal returns. Moreover, the imbalanced and continuous use of chemical fertilizers is leading to reduction in crop yields and adverse effect on soil health. Therefore, there is an urgent need to reduce the use of chemical fertilizers and at the same time increase soil fertility which are needed to enhance the yield and quality levels.

Application of organic manures has been a noble and traditional practice of maintaining soil health and fertility. The importance of organic manures is realized because of their inherent capacity to supply most essential nutrients for a balanced nutrition to the crop. Organic nutrients generally facilitate crop rooting, improve water retention capacity and result in the even distribution of nutrients in soil profile. Organic farming is meant for sustainable agriculture. It is a unique production management system which promotes the health of soil leading to production of healthy crop with better nutrient quality. Organic food (Green food) catches 2 to 5 times more market price ${ }^{2}$. Unfortunately the productivity of organically grown crop is less.

Liquid bio-fertilizers play a vital role in organic farming leading to green food production which is safer, healthier and tastier. The concept of bio-fertilizer is mentioned in Vrikshyaurveda under the generic name 'kunapajala' by Surpala (1000 AD) in eastern India ${ }^{3}$. Kunapajala is a fermentation product using easily available ingredients like Sesamum indicum L. (Tila), bone marrow, flesh (sheep, goat, fish etc), milk, black gram (Vigna mungo), ghee, honey etc. The beauty of kunapajala is that, it can be used on any plant at any growth stage. Firminger ${ }^{4}$ mentioned the beneficial use of liquid manure kunapajala for vegetable cultivation. According to Neff et al..$^{5}$ (2003), the reason behind the effectiveness of kunapajala is that the ingredients of kunapajala have been fermented, which means the proteins, fats, carbohydrates etc. are broken into simple low molecular weight products. Therefore, nutrients from kunapajala become available to the plants faster than from the traditionally applied organic matter. In addition, Patil ${ }^{6}$ (2007) mentioned that there is always a danger of passing on dormant pathogen to fields with plant based compost. But this is avoided by kunapajala because the kunapajala ingredients are cooked and fermented. So, it is concluded that the use of kunapajala enhances vegetative growth which leads to better yield with increased disease resistance under organic farming condition $^{7}$. Nene ${ }^{8}$ mentioned that, there is no fixed proportion for the ingredients of kunapajala and further research is needed to standardize the procedure and test it on crops. Mishra ${ }^{9}$ pointed out that kunapajala can be a good substitute to synthetic fertilizers. So, there is need to standardize kunapajala formulations and time and frequency for kunapajala application Shukla and Naik ${ }^{10}$ mentioned that the adequate supply of nutrients can increase the yield, fruit quality, fruit size, keeping quality, colour and taste of tomato. So, in order to improve the quality as well as quantity of tomato, the technology should be developed which eventually fulfills the need of both growers and consumers in organic way.

To address this short fall, it is intended to study the impact of kunapajala, a liquid biofertilizer from Vrikshayurveda on leaf of tomato (Lycopersicon esculentum L. cv. Selection 22) grown organically and to compare it with conventional farming and organic farming.

\section{METHODOLOGY}

The experiments were conducted at P.G. Research Centre, Department of Botany, Tuljaram Chaturachand College, Baramati, Dist. Pune, (M.S.) India (between $18^{\circ} 3^{\prime} \mathrm{N}$ to $18^{\circ} 12^{\prime}$ latitude, $74^{\circ} 13^{\prime} \mathrm{E}$ to $74^{\circ} 40^{\prime}$ E longitude and $548 \mathrm{~m}$ above mean sea level), in shade house using pot culture method. The earthen pots $(40 \times 40 \mathrm{~cm})$ were used for the experimentation. Conventional farming $(\mathrm{T}-1)$ was carried out by giving the treatment of NPK dose. Soil and vermicompost in 9:1 ratio were used for organic farming (T-2). Kunapajala (T3) was prepared as per formula of Deshmukh et al. ${ }^{7}$ and treatment was given to plants (20 DAS) for five times at the interval of 10 days by soil application method. The pots without any treatment were considered as control. The seeds of tomato (Lycopersicon esculentum L. cv. Selection 22) were sown randomly in these pots. The experiment was conducted in 20 replications.

Morphology of leaf of tomato was studied using routine laboratory methods. Freshly harvested third and fourth leaf from top of ten different plants were collected, cleaned properly and blotted dry. These were cut to small pieces and composite sample was prepared. This composite sample of leaf was used for physiological analysis. Osmotic potential of cell sap (OP) and membrane stability were measured by the methods proposed by 
Janardhan et al. ${ }^{11}$ and Premchandra et al. ${ }^{12}$ respectively. The photosynthetic pigments like chlorophylls and carotinoids were estimated by methods proposed by Arnon ${ }^{13}$ and Jensen ${ }^{14}$ respectively. The biochemical constituents were analyzed using the methods proposed by Lowry et al. ${ }^{15}$ for soluble proteins, Sadasivam and Manikam ${ }^{16}$ for total carbohydrates and for ascorbic acid, Grieve et al. ${ }^{17}$ for glycine betaine and Bates et al. ${ }^{18}$ for proline. The enzyme catalase was assayed according to the method described by Luck ${ }^{19}$. The activity of peroxidase enzyme was determined according to the method of Malik and $\operatorname{Singh}^{20}$ and that of polyphynol oxidase by Mahadevan and Shridhar ${ }^{21}$. Activities of super oxide dismutase and IAA oxidase were analyzed using the methods proposed by Giannopolitis and Ries ${ }^{22}$ and Tang and Bonner ${ }^{23}$ respectively.

\section{RESULTS AND DISCUSSION}

Impact of conventional farming (T-1), organic farming (T-2) and kunapajala treatment (T-3) on morphological parameter and water relations in leaf of tomato as on 60 DAS is shown in Table 1. The comparative study of different treatments with control showed that there was significant increase in number of leaves per plant, leaf area and leaf area index with T-1 (44\%, $121 \%$ and $40 \%)$, with T-2 $(25 \%, 81 \%$ and 50 $\%$ ) and with T-3 (46\%,121\% and $140 \%)$ respectively. Photoplate 1 showing the impact of conventional farming (T-1), organic farming (T-2) and kunapajala (T-3) treatment on morphology in leaves of tomato (Lycopersicon esculentum Mill. cv. Selection 22) as on 60 DAS. Plant size and leaf area are important variables in breeding for crop adaptation to water-limited environments. Singh $e t$ al. ${ }^{24}$ pointed out that leaf area index had significant positive correlation with total dry matter, total chlorophyll content, seed yield and harvest index. So, increase in leaf area index under T-3 treatment is significant for the productivity of tomato plant. As compared to the control, the total biomass was increase by $67 \%$ in T-1, $78 \%$ in T-2 and $141 \%$ in T-3 respectively on fresh weight basis and $97 \%, 114 \%$ and $290 \%$ in T-1, T-2 and T-3 respectively on dry weight basis. Kumar et al. ${ }^{25}$ and Singh $e t a l .{ }^{26}$ remarked that the attainment of biomass was significantly and positively correlated with seed yield. The T-3 treatment was effective in enhancing the morphological parameters of the leaves of tomato plant followed by T-1 and T-2. Relative water content (RWC) and osmotic potential (OP) of cell sap showed maximum increase under the influence of T-3 (30\% and $26 \%$ respectively), as against T-1 (8\% and $26 \%$ respectively) and T-2 (12\% and $6 \%$ respectively) compared to the control. About $95 \%$ of water absorbed by plant is lost through transpiration and about $5 \%$ of absorbed water is available for plant metabolism. So increase in RWC under present investigation is very significant for plant metabolism. Moreover, Sinclair and Ludlow ${ }^{27}$ reported that, plant metabolism is dependent on leaf water status. RWC has been proposed as a selection criteria for drought tolerance in many crops as reported by Schonfeld $e t a l^{28}$ in barley and Martin et al. ${ }^{29}$ in wheat. In the present study values of RWC and OP were highest in T-3 followed by T-1 and T-2 which play a significant role in decreasing membrane injury in T-1 by $17.1 \%$, in T-2 by $16.88 \%$ in T-3 by $15.94 \%$ compared to the control.

Table 2 reports the impact of conventional farming (T-1), organic farming (T-2) and kunapajala treatment (T-3) on photosynthetic pigments in leaves of tomato as on 60 DAS. A leaf is specialized for the process of photosynthesis. Productivity of crop plants is intimately associated with the photosynthetic pigments. Chlorophyll content is a good index to meet an overall evaluation of any crop for its photosynthetic ability. So, the productivity of any crop is linked with chlorophyll content, which decides the solar energy harnessing ability of plant. As compared to the control, the chlorophyll a showed nearly same increase with T-1 and T-3 by $49 \%$ followed by T-2 (29\%) treatment. However, chlorophyll b showed more increase with T-3 (23\%) followed by T-1 (22\%) and T-2 (10\%) respectively. Chlorophyll b absorbs energy from light and transfers it to chlorophyll a. The total chlorophylls and chlorophyll stability index increased by $37 \%$ and $53 \%$ in T-1, 21 \% and $62 \%$ in T-2 and $38 \%$ and $67 \%$ in T-3 treatment. The chlorophyll stability index (CSI) is an important index for screening plant tolerance to abiotic stresses ${ }^{30,31}$. Carotenoids and xanthophylls increased by $5 \%$ and $9 \%$ respectively in T-1, $2 \%$ and $52 \%$ respectively in T-2 and $6 \%$ and $68 \%$ in T-3 compared to the control. Carotenoids react directly with singlet oxygen to detoxify it or they can quench the chlorophyll sensitizer and thus prevent singlet oxygen production ${ }^{32}$. They react with singlet oxygen to produce carotenoid triplet which then decays harmlessly producing heat, rather than any toxic product. Secondly, carotenoids react with chlorophyll triplets to produce carotenoid triplets and this effectively prevents the generation of singlet oxygen and also reduces life time of chlorophyll triplet which is the major photo-protective mechanism. This requires the carotenoid and chlorophyll molecules to be arranged precisely in very close proximity to each other. Both pigments are attached to the same protein forming a complex called Photosynthin ${ }^{33}$. Carotenoids absorb light in the blue region of the spectrum (400 to $600 \mathrm{~nm}$ ), and the energy absorbed can be transferred to chlorophylls. Therefore, carotenoids serve as accessory pigments by harvesting radiant light in a region of the spectrum not covered by the chlorophylls. In addition, carotenoids are essential for photo-protection. In the absence of colored carotenoids, plants suffer severe photo-oxidative damage, which generally results in the death of the organism. The likely mechanism for photo-protection is the quenching of chlorophyll triplets by colored carotenoids that would otherwise lead to the generation of oxygen singlet that can react with lipids, proteins, and 
other macromolecules, causing irreparable damage ${ }^{34,35}$. There is considerable evidence in support of a photoprotective role of the xanthophyll cycle in the removal of excess excitation energy from the photosynthetic antennae $^{36}$.

Table 3 exhibits the impact of conventional farming (T-1), organic farming (T-2) and kunapajala treatment (T-3) on bio-organics in leaves of tomato as on 60 DAS. In present investigation, there was increase in soluble proteins, total carbohydrates and polyphenol content with $\mathrm{T}_{1}(67 \%, 57 \%$ and $129 \%$ respectively), with $\mathrm{T}_{2}\left(67 \%, 19 \%\right.$ and $113 \%$ respectively) and with $\mathrm{T}_{3}(74 \%, 55 \%$ and $197 \%$ respectively) compared to the control. Protein synthesis turnover in growing plants is a basic component of metabolic regulation which provides a way for varying the enzymatic complement during the response to environmental conditions ${ }^{37}$. Protein and carbohydrate content increased in all treatments compared to the control. It showed maximum content in T-3 treated plants. All the functions of life depend upon protein. The significantly increase in soluble protein content in the present investigation is well related to increase in photosynthetic pigment content leading to increase in photosynthetic ability of plant ${ }^{6}$. According to Ferrari et al. ${ }^{38}$, protein is the antioxidant group which protects the plant from stress induced free radical formation. So, the enhanced soluble protein content in T-3 plants in present investigation might be contributing to enhanced growth and yield. Carbohydrates are involved in structural organization of many tissues in plants. Both proteins and carbohydrates are the chief sources of energy in the living cells and are involved in ATP synthesis through oxidation process. The oxidation also produces several important intermediate compounds, which serve as carbon sources for the synthesis of amino acids, lipids and other important bio-molecules. The increase in biochemical constituents might be helpful to improve growth and yield. The term "phenolic" or "polyphenol" can be precisely defined chemically as a substance which possesses an aromatic ring bearing one (phenol) or more (polyphenol) hydroxyl substituents, including functional derivatives (esters, methyl ethers, glycosides, etc.) as a general rule. The phenolics and polyphenols arise biogenetically from the shikimate-phenylpropanoids-flavonoids pathways, producing monomeric and polymeric phenols and polyphenols ${ }^{39}$. Vincenzo et al. ${ }^{40}$ reported that plants need phenolic compounds for pigmentation, growth, reproduction, resistance to pathogens and for many other functions. In the present investigation, as compared to control, the proline and glycine betaine showed increase highest with T-3 (69 \% and $414 \%)$ followed by T-1 (23\% and $274 \%)$ and T-2 (46\% and $180 \%)$ respectively. Proline has multiple functions, such as osmotic pressure regulation, protection of membrane integrity, stabilization of enzymes/proteins, maintenance of appropriate NADP+/NADPH ratios and scavenger of free radicals ${ }^{41,42,43}$ and as a major source of energy and nitrogen during immediate post-stress metabolism, thereby inducing salinity tolerance ${ }^{44}$. Over-accumulation of proline under either salt stress or antioxidant application or their interactions in plants, has been attributed to the strategies adapted by plants to cope up with stress conditions ${ }^{45}$. Many authors indicate the importance of soluble carbohydrates in stimulating proline accumulation through an inhibition of the degradation enzymes of proline ${ }^{46}$ and synthesis of enzymes of proline formation. Glycine betaine (GlyBet), a quaternary ammonium compound, is regarded as one of the most effective osmoprotectants owing to its many advantages besides its efficacy as a compatible solute. The molecular features of GlyBet enable its interaction with both the hydrophobic and hydrophilic domains of macromolecules without perturbing the cellular functions ${ }^{47}$. Ma et al ${ }^{48}$ have also reported that GlyBet induced the accumulation of osmolytes, such as soluble sugars and free proline. In present study, ascorbic acid content increased significantly by $33 \%$ with $\mathrm{T}-1$, by $15 \%$ with $\mathrm{T}-2$ and by $37 \%$ with T-3 respectively compared to the control. Horeman et al. ${ }^{49}$ stated that ascorbic acid is involved in other functions such as plant growth, gene regulation, and modulation of some enzymes and redox regulation of membrane -bound antioxidant compounds.

Figure - 1 represents the impact of conventional farming (T-1), organic farming (T-2) and kunapajala treatment (T-3) on oxidative enzyme activity in leaves of tomato as on 60 DAS. Enzymatic activity is correlated with cell division and cell differentiation at various stages of leaf development ${ }^{50}$. In the present investigation as compared to control, there was increase in the activity of catalase (CAT), peroxidase (POD), polyphenol oxidase (PPO), IAA Oxidase (IAO) and super oxide dismutase (SOD) under T-1 $(1.5 \%, 33.33 \%,-43 \%, 29 \%$ and $5 . \%$ respectively), T-2 $(0.08 \%, 75 \%, 71 \%, 9.5 \%$ and $56 \%$ respectively) and T-3 $(12 \%, 83 \%, 100 \%, 45 \%$ and $70.5 \%$ respectively). Gogorcena $e t a l .{ }^{51}$ and Bergmann $e t$ al..$^{52}$ reported that antioxidative enzymes were related with water deficiency and they were considered the main components of anti-oxidative machinery for drought resistance in higher plants. According to Shigeoka et al. ${ }^{53}$, peroxidase catalyses the dehydrogenation of structurally diverse phenolic substrates by $\mathrm{H}_{2} \mathrm{O}_{2}$ and are thus often regarded as antioxidant enzymes. Sen and Mukharji ${ }^{54}$ reported that IAA oxidase controls IAA levels in plants and is hence responsible for regulating growth. The present study shows that T-3 leads to more increase in activity of polyphenol oxidase and IAA oxidase compared to the peroxidase and superoxide dismutase enzyme activity. This leads to increase in antioxidant properties of tomato plant, which is significant. Djianaguiraman $e t a l .{ }^{55}$ concluded that SOD activity and the removal of $\mathrm{H}_{2} \mathrm{O}_{2}$ by catalase and peroxidase are necessary for an effective defense against the action of free radicals. SOD plays an important role in protecting cell against the toxic effects of superoxide radicals produced 
during oxidative burst ${ }^{55}$. In the present investigation, highest activity of super oxide dismutase was observed in T-3 plants.

As a whole, the present investigation shows that the number of leaves per plant, leaf area and biomass were highest in T-3 treatment, while leaf area was same in T-1 and T-3 treatment. Membrane injury was lowest in T-3 treatment followed T-1 and T-2. Cholorophyll content showed nearly same increase in T-3 and T-1 over T-2. Chlorophyll stability index and xanthophylls were highest in T-3, followed by T-1 and T-2. There was significant increase in soluble proteins, total carbohydreates, polyphenols, ascorbic acid, proline and glycine betaine under T-3 treatment keeping T-1 in second rank. T-3 acquired first position in activity of oxidative enzymes such as catalase, peroxidase, polyphenol oxidase, IAA oxidase and super oxide dismutase.

\section{REFERENCES}

[1]. Jagadeesha V, Effect of organic manures and biofertilizers on growth, seed yield and quality in tomato (Lycopersicon esculentum Mill) cv. Megha. Ph D Thesis, (Department of seed science and Technology, College of agriculture, Dharwad, University of Agricultural Sciences, Dharwad, India), 2008.

[2]. Subramanian VTC, Organic farming in India: Prospects and Challenges. In: Trends in Organic Farming, edited by Purohit SS. \& Gehlot D., (Agrobios, Jodhpur, India), 2006, 29-38.

[3]. Sadhale N (Translator), Surapala's Vrikshayurveda (The Science of Plant Life). In: Asian Agri History Bulletin-1 (Asian Agri History Foundation (AAHF), Secunderabad, Andhra Pradesh, India), 1996, 48-55.

[4]. Firminger TAC, Manual of gardening for Bengal and Upper India. (R. C. Lepage Co. London, U.K. and Calcutta. India), 1864, 558

[5]. Patil NA, Techinques In Ancient Indian Literature for increasing crop productivity. Final Report of UGC Research Project, (2007).

[6]. Neff JC, Chapin III FS \& Vitousek PM, Breaks in the cycle: dissolved organic nitrogen in terrestrial ecosystems. Frontiers in Ecology and the environment, 1(4) (2003) 205-211

[7]. Deshmukh RS, Patil NA \& Nikam TD, Kunapajala: Formulation and Standardization of Dosages for Cultivation of Tomato. In: Proceedings of International Conference on Traditional Practices in Conservation Agriculture. 1820 September, 2010 (Janardhan Rai Nagar, Rajasthan Vidyapeeth University, Pratap Nagar, Udaipur, Rajasthan, India), edited by Choudhary SL, Khandelwal SK \& Nene YL. (Asian Agri History Foundation, Secunderabad, India), 2011, 125 - 132.

[8]. Nene YL, Utilization of Traditional knowledge in agriculture. Journal of Traditional Knowledge System of India and Sri Lanka. (Asian Agri History Foundation, Secunderabad, India), 2006, 32-38.

[9]. Mishra PK, Effects of Kunapajalam Vrikshayurveda on growth of paddy. J. Indian Journal of Traditional Knowledge 6(2) (2007) 307-310.

[10]. Shukla V \& Naik LB, Agro-techniques for Solanaceous Vegetables. In: Vegetable Crops: Part-I, Advances in Horticulture, Vol. V, edited by Chadha KL and Kalloo G., (Malhotra Pulishing House, New Delhi, India), 1993, 371.

[11]. Janardhan K, Murthy PV, Giriraj K \& Panchakshariah S, A rapid method for determination of osmotic potential of plant sap. Current Science, 44 (1976) 390.

[12]. Premchandra GS, Soneoka H \& Ogata S, Cell membrane stability, an indicator of drought tolerance as affected by applied nitrogen in soyabean. Journal of Agricutural Science, Cambridge, 115 (1990) 63-66.

[13]. Arnon D I, Copper enzymes in isolated chloroplasts, polyphenol oxidase in Beta vulgaris L. Plant Physiology, 24 (1949) 1-15.

[14]. Jensen A., Estimation of chlorophyll and carotenoids. In: Hand book of physiological Methods-Chlorophyll and Carotenoids (Cambridge University Press, London. UK), 1978, 59 -70.

[15]. Lowry OH, Rosebrough NT, Farr AL \& Randall RJ, Protein measurement with folin phenol reagent. Journal of Biological Chemistry 193 (1951) 265-275.

[16]. Sadashivam S \& Manikam A, Biochemical Methods. Second Edition (New Age International, New Delhi, India), 2005.

[17]. Grieve CM \& Grattan SR, Rapid assay for determination of water soluble quaternary amino compounds. Plant Soil, 70 (1983) 303-307.

[18]. Bates LS, Waldren RP \& Tease ID, Rapid determination of free proline for water stress studies. Plant and Soil, 39 (1973) 205-207.

[19]. Luck H., Methods in Enzymatic Analysis, edited by Bergmeyer (Academic Press, New York), 1974, 885.

[20]. Malik CP \& Singh MB, Plant Enzymology and Histoenzymology, (Kalyani Publishers, New Delhi, India), 1980.

[21]. Mahadevan A \& Shridhar R, Methods in physiological plant pathology, second edition. (Sivakami, Madras, India), 1982.

[22]. Giannopolitis CN \& Ries SK, Super oxide dismutase. I. Occurrence in higher plants. Plant Physiology, 59 (1977) $309-314$.

[23]. Tang YW \& Bonner RA, The enzymatic inactivation of IAA. Arch. Biochem. Biophysics, 13 (1947) 11.

[24]. Singh TP, Deshmukh PS, Kumar P, Relationship between physiological traits in chickpea (Cicer arietium L.) under rainfed condition. Indian J. Plant Physiology, 13(4) (2008) 411 - 413.

[25]. Kumar P, Deshmukh PS, Kushwaha SR \& Kumari S, Effect of terminal drought on biomass production, its partitioning and yield of chickpea genotype. Ann. Agri. Res, 22 (2001) 408 - 411.

[26]. Singh TP, Deshmukh PS \& Kushwaha SR, Physiological studies on temperature tolerance in chickpea (Cicer arietium L.) genotypes. Indian J. Plant Physiology, 9 (2004) 294 - 301. 
[27]. Sinclair TR \& Ludlow MM, Who taught plants thermodynamics? The unfulfilled potential of plant water potential. Aust. J. of Plant Physiology, 12 (1985) 213 - 217.

[28]. Schonfled MA, Johnson RC \& Carver BF, Mornhinweg DW, Water relations in winter wheat as drought resistance indicators. Crop Science, 28(3) (1988) 526-531.

[29]. Martin AE, Burgess BK, Ismaa SE, Smart CT \& Dean DR, Construction and characterization of an Azotobacter vinelandii with mutation in the genes encoding flavodoxin and ferredoxin. J. Bacteriol, 171 (1989) 3162-3167.

[30]. Gomaz MS \& Rangasamy P, Correlation and path analysis of yield and physiological characters in drought resistant rice (Oryza sativa L.). International Journal of Mendel, 19(1-2) (2002) 33 - 34.

[31]. Yagameena K, Genetic analysis for drought tolerance in rice (Oryza sativa L.). M.Sc. Thesis (Tamil Nadu Agricultural Univ., Coimbatore, India), 2004.

[32]. Foote CS, Singlet oxygen in biological systems. In: Free radicals and biological systems, edited by Pryor WA (Academic Press, New York), 1976, 85 -133.

[33]. Datta SC, Plant physiology (New Age International Ltd., New Delhi, India), 2003, 207.

[34]. Krinsky NI, Carotenoid protection against photo-oxidation. Pure Appl. Chem, 51 (1979) 649 - 660.

[35]. Davidson E \& Cogdell RJ, Reconstitution of carotenoids into the light-harvesting pigment-protein complex from the carotenoid-less mutant of Rhodopseudomonas sphemides R 26. Biochim. Biophys. Acta, 635 (1981) 295-303.

[36]. Demmig-Adams B \& Adams WW, The xanthophyll cycle. In: Antioxidants in Higher Plants, edited by R. G. Alscher and J. L. Hess (CRC Press, London, UK), 1993, 91-110.

[37]. Huffaker RC \& Peterson LW, Protein turnover in plants and possible means of its regulation. Ann. Rev. P1. Physiol., 25 (1974) 363 - 392.

[38]. Ferrari IR, Anh-Thu PT, Mazliak P \& Da-Silva JV, Natural mechanisms for protecting higher plants from oxygen reactive species. Annee-Biologique, 31(3) (1994) 115 - 136.

[39]. Harborne JB, Plant phenolics. In: Methods in Plant Biochemistry, Vol. I, edited by Dey P M. \& Harborne JB (Academic Press, London, UK), 1989.

[40]. Vincenzo L, Veronica MT, Lattanzio \& Cardinali A, Role of phenolics in the resistance mechanisms of plants against fungal pathogens and insects. Phytochemistry: Advances in Research, 37/661(2) (2006) 23-67.

[41]. Tripathi SB, Gurumurthi K, Panigrahi AK \& Shaw BP. Salinity induced changes in proline and betaine contents and synthesis in two aquatic macrophytes differing in salt tolerance. Biol. Plant, 51 (2007) 110 - 115.

[42]. Kaymakanova M \& Stoeva N, Physiological reactions of bean plants (Phaseolus vulg. L.) to salt stress. Gen. Appl. Plant Physiol., 34(3-4) (2008) 177 - 188.

[43]. Misra N. \& Saxena P, Effect of salicylic acid on proline metabolism in lentil grown under salinity stress. Plant Science, 177 (2009) $181-189$.

[44]. Jain M, Mathur G, Koul S \& Sarin NB, Ameliorating effects of proline on salt stress lipid peroxidation in cell lines of groundnut (Arachis hypogaea L.). Plant Cell Report, 20 (2001) 463 - 468.

[45]. Alqurainy F, Responses of bean and pea to vitamin C under salinity stress. Research Journal of Agriculture and Biological Sciences, 3(6) (2007) 714 - 722.

[46]. Heineke D, Sonnewald U, Bussis D, Gunter G, Leidreiter K, Wilke I, Rashke K, Willmitzer L \& Heldt HW, Apo plastic expression of yeast-derived invertase in potato. Plant Physiology 100 (1992) 301 - 308.

[47]. Sakamoto A \& Murata N, Genetic engineering of glycine betaine synthesis in plants: current status and implications for enhancement of stress tolerance. J. Exp. Bot., 51 (2000) 81-88.

[48]. Ma QQ, Zou Q, Li YH, Li DQ \& Wang W, Amelioration of the water status and improvement of the antioxidant enzyme activities by exogenous glycine betaine in water-stressed wheat seedlings. Acta Agron.Sinica, 4 (2004) $321-328$.

[49]. Horeman N \& Foyer CH, Asard H. Transport and action of ascorbate at the plant plasma membrane. Trends Plant Sci., 5 (2000) 263 - 267.

[50]. Maksymowych R \& Kettrick MA, DNA Synthesis, Cell Division, and Cell Differentiation during Leaf Development of Xanthium pennsylvanicum. American Journal of Botany, 57(7) (1970) 844-849.

[51]. Gogorcena Y, Iturbe I, Ormaetxe P, Escuredo R \& Becana M. Antioxidant defenses against activated oxygen in pea nodules subjected to water stress. J. Plant Physiol 108 (1995) 753-758.

[52]. Bergmann H, Lippmann B, Leinhos V, Tiroke S \& Machelett B, Activation of stress resistance in plants and consequences for product quality. J. Appl. Bot. 73 (1999) 153-161.

[53]. Shigeoka S, Ishikawa T, Tamoi M, Miyagawa Y, Takeda T, Yabuta Y \& Yoshimura K, Regulation and function of ascorbate peroxidase isoenzymes, J. Exp. Bot., 53 (2002) 1305-1319.

[54]. Sen S \& Mukherji S, Season controlled changes in biochemical constituents and oxidase enzyme activities in tomato (Lycopersicon esculentum Mill). Journal of Environmental Biology, 30(4) (2009) 479 - 483.

[55]. Djanaguiramam M, Pandiyan M \& Durga Devi D, Abscission of tomato fruit follows oxidative damage and its manipulation by ANTONIC spray. International Journal of Agriculture and Biology, 7(1) (2005).

[56]. Halliwell B \& Gutteridge JMC, Free radicals in biology and medicine (Oxford University Press, Oxford, UK), 2000 . 
Table - 1: Impact of conventional farming (T-1), organic farming (T-2) and kunapajala (T-3) treatment on morphology and water relations in leaves of tomato (Lycopersicon esculentum L. cv. Selection 22) as on 60 DAS.

\begin{tabular}{|c|c|c|c|c|c|}
\hline \multirow[b]{2}{*}{$\begin{array}{l}\text { Sr. } \\
\text { No. }\end{array}$} & \multirow[b]{2}{*}{ Parameters } & \multirow[b]{2}{*}{ Control } & \multicolumn{3}{|l|}{ Treatments } \\
\hline & & & $\begin{array}{l}\text { Conventional } \\
\text { farming } \\
(\mathrm{T}-1)\end{array}$ & $\begin{array}{l}\text { Organic } \\
\text { farming } \\
(\mathrm{T}-2)\end{array}$ & $\begin{array}{l}\text { Kunapajala } \\
(\mathrm{T}-3)\end{array}$ \\
\hline 01 & $\begin{array}{l}\text { Number of leaves / } \\
\text { plant }\end{array}$ & $\begin{array}{l}8.23^{\mathrm{c}} \\
\pm 0.66\end{array}$ & $\begin{array}{l}11.84^{a, b} \\
\pm 0.12\end{array}$ & $\begin{array}{l}10.31^{b} \\
\pm 0.11\end{array}$ & $\begin{array}{l}12.01^{\mathrm{a}} \\
\pm 0.33\end{array}$ \\
\hline 02 & Leaf area $\left(\mathrm{cm}^{2}\right)$ & $\begin{array}{l}162.3^{\mathrm{c}} \\
\pm 1.2\end{array}$ & $\begin{array}{l}358.5^{\mathrm{a}} \\
\pm 1.54\end{array}$ & $\begin{array}{l}294.1^{\mathrm{b}} \\
\pm 1.64\end{array}$ & $\begin{array}{l}358.5^{\mathrm{a}} \\
\pm 1.44\end{array}$ \\
\hline 03 & Leaf area index & $\begin{array}{l}0.10^{\mathrm{c}} \\
\pm 0.5\end{array}$ & $\begin{array}{l}0.14^{\mathrm{b}} \\
\pm 0.5\end{array}$ & $\begin{array}{l}0.15^{\mathrm{b}} \\
\pm 0.2\end{array}$ & $\begin{array}{l}0.24^{\mathrm{a}} \\
\pm 0.5 \\
\end{array}$ \\
\hline \multirow[t]{3}{*}{04} & Biomass : & & & & \\
\hline & A. Fresh wt. (g) & $\begin{array}{l}3.826^{\mathrm{d}} \\
\pm 1.88 \\
\end{array}$ & $\begin{array}{l}6.396^{\mathrm{c}} \\
\pm 1.45\end{array}$ & $\begin{array}{l}6.820^{\mathrm{b}} \\
\pm 1.88\end{array}$ & $\begin{array}{l}9.217^{\mathrm{a}} \\
\pm 1.74\end{array}$ \\
\hline & B. Dry wt. (g) & $\begin{array}{l}0.621^{\mathrm{d}} \\
\pm 0.86\end{array}$ & $\begin{array}{l}1.224^{\mathrm{c}} \\
\pm 0.64\end{array}$ & $\begin{array}{l}1.328^{b} \\
\pm 0.35\end{array}$ & $\begin{array}{l}2.424^{\mathrm{a}} \\
\pm 0.77\end{array}$ \\
\hline 05 & $\begin{array}{ll}\text { Relative } & \text { water } \\
\text { content }(\%)\end{array}$ & $\begin{array}{l}47.18^{\mathrm{d}} \\
\pm 0.52 \\
\end{array}$ & $\begin{array}{l}51.08^{\mathrm{c}} \\
\pm 0.47\end{array}$ & $\begin{array}{l}52.76^{\mathrm{b}} \\
\pm 0.32 \\
\end{array}$ & $\begin{array}{l}53.17^{\mathrm{a}} \\
\pm 0.31\end{array}$ \\
\hline 06 & $\begin{array}{l}\text { Osmotic potential of } \\
\text { cell sap (- bar) }\end{array}$ & $\begin{array}{l}-4.816^{\mathrm{d}} \\
\pm 0.83\end{array}$ & $\begin{array}{l}-3.553^{\mathrm{a}} \\
\pm 0.34\end{array}$ & $\begin{array}{l}-4.537^{\mathrm{c}} \\
\pm 0.48\end{array}$ & $\begin{array}{l}-3.550^{\mathrm{b}} \\
\pm 0.24\end{array}$ \\
\hline 07 & $\begin{array}{l}\text { Membrane injury } \\
(\%)\end{array}$ & $\begin{array}{l}25.0^{\mathrm{a}} \\
\pm 0.79\end{array}$ & $\begin{array}{l}17.1^{\mathrm{b}} \\
\pm 0.36 \\
\end{array}$ & $\begin{array}{l}16.88^{\mathrm{c}} \\
\pm 0.13 \\
\end{array}$ & $\begin{array}{l}15.94^{\mathrm{d}} \\
\pm 0.52 \\
\end{array}$ \\
\hline
\end{tabular}

Data presented in the table are mean \pm SE scored after 60 days from 10 plants per treatment and experiment repeated thrice. Mean followed by same letters are not significantly different at $P \leq 0.05$ level by Duncan's multiple range test.

Table - 2: Impact of conventional farming $\left(\mathrm{T}_{1}\right)$, organic farming $\left(\mathrm{T}_{2}\right)$ and kunapajala treatment $\left(\mathrm{T}_{3}\right)$ on photosynthetic pigments in leaves of tomato (Lycopersicon esculentum L. cv. Selection 22) as on 60 DAS.

\begin{tabular}{|c|c|c|c|c|c|}
\hline \multirow{2}{*}{$\begin{array}{l}\text { Sr. } \\
\text { No. }\end{array}$} & \multirow{2}{*}{ Parameters } & \multirow{2}{*}{ Control } & \multicolumn{3}{|c|}{ Treatments } \\
\hline & & & $\begin{array}{l}\text { Conventional } \\
\text { farming } \\
(\mathrm{T}-1)\end{array}$ & $\begin{array}{l}\text { Organic } \\
\text { farming } \\
(\mathrm{T}-2)\end{array}$ & $\begin{array}{l}\text { Kunapajala } \\
(\mathrm{T}-3)\end{array}$ \\
\hline 01 & $\begin{array}{l}\begin{array}{l}\text { Chlorophyll } \\
\text { (mg / g fresh wt.) }\end{array} \\
\end{array}$ & $\begin{array}{l}79.55^{\mathrm{c}} \\
\pm 1.03 \\
\end{array}$ & $\begin{array}{l}118.78^{\mathrm{a}} \\
\pm 1.47 \\
\end{array}$ & $\begin{array}{l}102.35^{\mathrm{b}} \\
\pm 1.25 \\
\end{array}$ & $\begin{array}{l}118.73^{\mathrm{a}} \\
\pm 1.11 \\
\end{array}$ \\
\hline 02 & $\begin{array}{l}\text { Chlorophyll } \\
\text { (mg / g fresh wt.) }\end{array}$ & $\begin{array}{l}59.55^{\mathrm{c}} \\
\pm 0.90 \\
\end{array}$ & $\begin{array}{l}72.78^{\mathrm{a}, \mathrm{b}} \\
\pm 1.154\end{array}$ & $\begin{array}{l}65.49^{\mathrm{b}} \\
\pm 1.42 \\
\end{array}$ & $\begin{array}{l}73.23^{\mathrm{a}} \\
\pm 1.12 \\
\end{array}$ \\
\hline 03 & $\begin{array}{l}\text { Total chlorophylls } \\
\text { (mg / g fresh wt.) }\end{array}$ & $\begin{array}{l}139.1^{\mathrm{c}} \\
\pm 1.34 \\
\end{array}$ & $\begin{array}{l}191.56^{\mathrm{a}} \\
\pm 1.78\end{array}$ & $\begin{array}{l}167.84^{\mathrm{b}} \\
\pm 1.25 \\
\end{array}$ & $\begin{array}{l}191.96^{\mathrm{a}} \\
\pm 1.13 \\
\end{array}$ \\
\hline 04 & $\begin{array}{l}\text { Chlorophyll stability } \\
\text { Index }\end{array}$ & 0.57 & 0.87 & 0.92 & 0.95 \\
\hline 05 & $\begin{array}{l}\text { Carotenoids } \\
(\mathrm{mg} / 100 \mathrm{~g})\end{array}$ & $\begin{array}{l}19.91^{\mathrm{c}} \\
\pm 0.33 \\
\end{array}$ & $\begin{array}{l}21.01^{\mathrm{a}, \mathrm{b}} \\
\pm 0.56 \\
\end{array}$ & $\begin{array}{l}20.37^{\mathrm{b}} \\
\pm 0.35 \\
\end{array}$ & $\begin{array}{l}21.14^{\mathrm{a}} \\
\pm 0.47 \\
\end{array}$ \\
\hline 06 & $\begin{array}{l}\text { Xanthophylls } \\
(\mathrm{mg} / 100 \mathrm{~g})\end{array}$ & $\begin{array}{l}4.32^{\mathrm{d}} \\
\pm 0.29\end{array}$ & $\begin{array}{l}4.72^{\mathrm{c}} \\
\pm 0.63 \\
\end{array}$ & $\begin{array}{l}6.56^{\mathrm{b}} \\
\pm 0.13\end{array}$ & $\begin{array}{l}7.28^{\mathrm{a}} \\
\pm 0.47\end{array}$ \\
\hline
\end{tabular}


Data presented in the table are mean \pm SE scored after 60 days from 10 plants per treatment and experiment repeated thrice. Mean followed by same letters are not significantly different at $P \leq 0.05$ level by Duncan's multiple range test.

Table - 3: Impact of conventional farming (T-1), organic farming (T-2) and kunapajala treatment (T-3) on bioorganics in leaves of tomato (Lycopersicon esculentum L. cv. Selection 22) as on 60 DAS.

\begin{tabular}{|c|c|c|c|c|c|}
\hline \multirow{2}{*}{$\begin{array}{l}\text { Sr. } \\
\text { No. }\end{array}$} & \multirow{2}{*}{ Parameters } & \multirow{2}{*}{ Control } & \multicolumn{3}{|l|}{ Treatments } \\
\hline & & & $\begin{array}{l}\text { Conventional } \\
\text { farming } \\
(\mathrm{T}-1)\end{array}$ & $\begin{array}{l}\text { Organic } \\
\text { farming } \\
(\mathrm{T}-2)\end{array}$ & $\begin{array}{l}\text { Kunapajala } \\
(\mathrm{T}-3)\end{array}$ \\
\hline 01 & $\begin{array}{l}\text { Soluble proteins } \\
\text { (g } 100^{-1} \mathrm{~g} \text { fresh } \\
\text { wt.) }\end{array}$ & $\begin{array}{l}7.60^{\mathrm{c}} \\
\pm 0.66\end{array}$ & $\begin{array}{l}12.7^{\mathrm{b}} \\
\pm 0.11\end{array}$ & $\begin{array}{l}12.7^{\mathrm{b}} \\
\pm 0.33\end{array}$ & $\begin{array}{l}13.2^{\mathrm{a}} \\
\pm 0.1\end{array}$ \\
\hline 02 & $\begin{array}{l}\text { Total } \\
\text { carbohydrates } \\
\text { (g } 100^{-1} \mathrm{~g} \text { fresh } \\
\text { wt.) }\end{array}$ & $\begin{array}{l}12.1^{\mathrm{d}} \\
\pm 0.22\end{array}$ & $\begin{array}{l}19.0^{\mathrm{a}} \\
\pm 0.5\end{array}$ & $\begin{array}{l}14.44^{\mathrm{c}} \\
\pm 0.22\end{array}$ & $\begin{array}{l}18.80^{\mathrm{b}} \\
\pm 0.5\end{array}$ \\
\hline 03 & $\begin{array}{l}\text { Polyphenols } \\
\text { (g } 100^{-1} \mathrm{~g} \text { fresh } \\
\text { wt.) }\end{array}$ & $\begin{array}{l}3.008^{\mathrm{d}} \\
\pm 1.6\end{array}$ & $\begin{array}{l}6.883^{\mathrm{b}} \\
\pm 1.20\end{array}$ & $\begin{array}{l}6.412^{\mathrm{c}} \\
\pm 1.33\end{array}$ & $\begin{array}{l}8.930^{\mathrm{a}} \\
\pm 1.33\end{array}$ \\
\hline 04 & $\begin{array}{l}\text { Proline } \\
\text { (g/ } 100 \text { g dry wt.) }\end{array}$ & $\begin{array}{l}0.13^{\mathrm{d}} \\
\pm 0.32\end{array}$ & $\begin{array}{l}0.16^{\mathrm{c}} \\
\pm 0.64\end{array}$ & $\begin{array}{l}0.19^{\mathrm{b}} \\
\pm 0.83\end{array}$ & $\begin{array}{l}0.22^{\mathrm{a}} \\
\pm 0.5\end{array}$ \\
\hline 05 & $\begin{array}{l}\text { Glycine betaine } \\
\text { (g/100 g dry wt.) }\end{array}$ & $\begin{array}{l}0.214^{\mathrm{c}} \\
\pm 0.66 \\
\end{array}$ & $\begin{array}{l}0.80^{\mathrm{a}, \mathrm{b}} \\
\pm 0.36 \\
\end{array}$ & $\begin{array}{l}0.60^{\mathrm{b}} \\
\pm 0.51 \\
\end{array}$ & $\begin{array}{l}1.10^{\mathrm{a}} \\
\pm 0.16 \\
\end{array}$ \\
\hline 06 & $\begin{array}{l}\text { Ascorbic acid } \\
(\mathrm{mg} / 100 \mathrm{~g} \text { fresh } \\
\text { wt.) }\end{array}$ & $\begin{array}{l}11.36^{\mathrm{d}} \\
\pm 1.88\end{array}$ & $\begin{array}{l}15.10^{\mathrm{b}} \\
\pm 1.65\end{array}$ & $\begin{array}{l}13.77^{\mathrm{c}} \\
\pm 1.35\end{array}$ & $\begin{array}{l}15.60^{\mathrm{a}} \\
\pm 1.69\end{array}$ \\
\hline
\end{tabular}

Data presented in the table are mean \pm SE scored after 60 days from 10 plants per treatment and experiment repeated thrice. Mean followed by same letters are not significantly different at $P \leq 0.05$ level by Duncan's multiple range test

\section{FIGURE}

Fig. 1: Impact of conventional farming (T-1), organic farming (T-2) and kunapajala (T-3) on enzyme activity in leaves of tomato (Lycopersicon esculentum L. cv. Selection 22) as on 60 DAS.

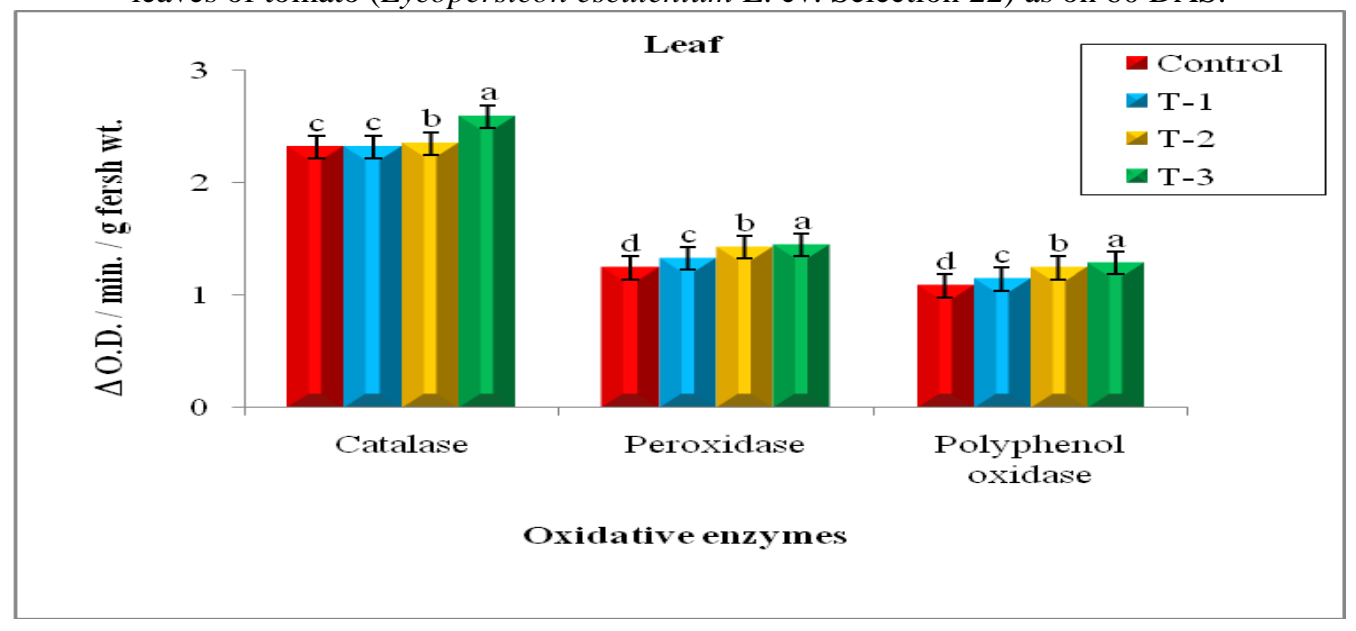




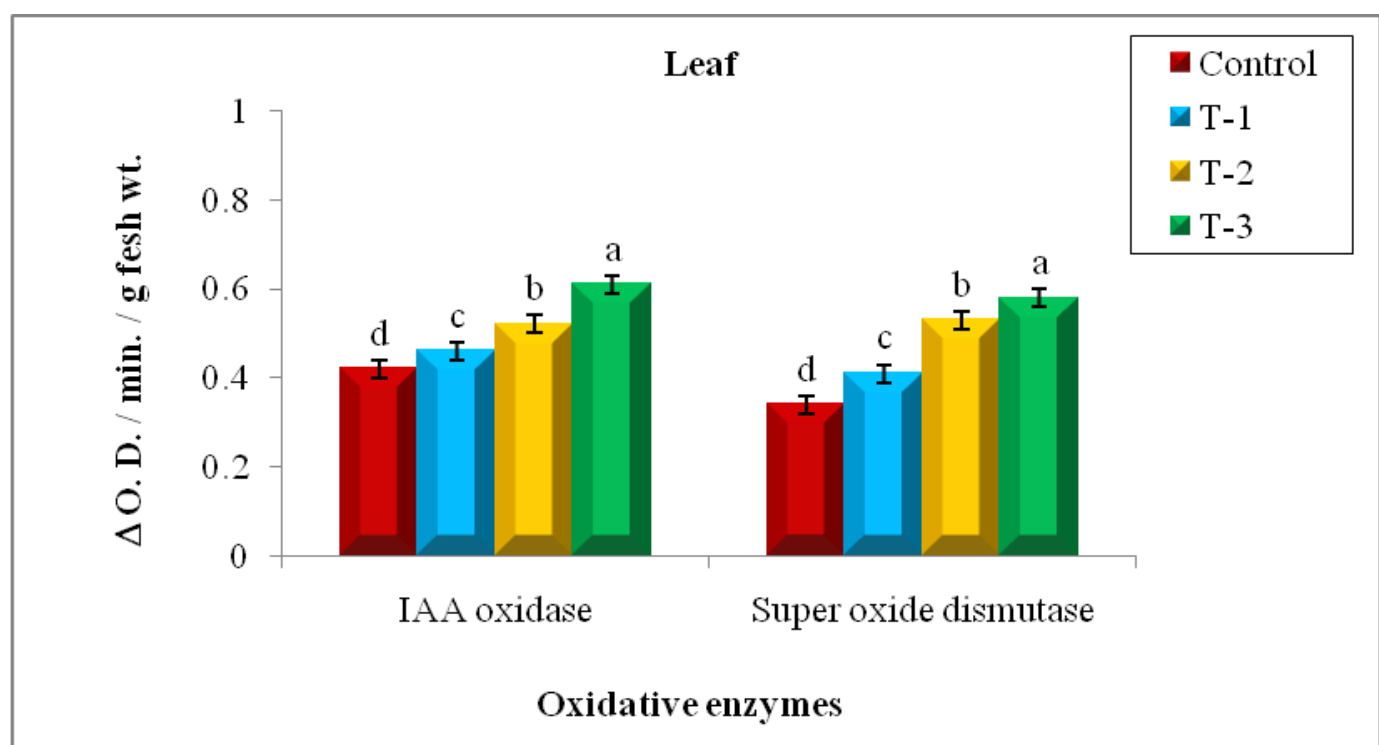

Data presented in the Figures are mean \pm SE scored after 60 days from 10 plants per treatment and experiment repeated thrice. Mean followed by same letters are not significantly different at $P \leq 0.05$ level by Duncan's multiple range test.

\section{PHOTO PLATE}

Photo plate 1: Impact of conventional farming (T-1), organic farming (T-2) and kunapajala (T-3) treatment on morphology in leaves of tomato (Lycopersicon esculentum Mill. cv. Selection 22) as on 60 DAS.

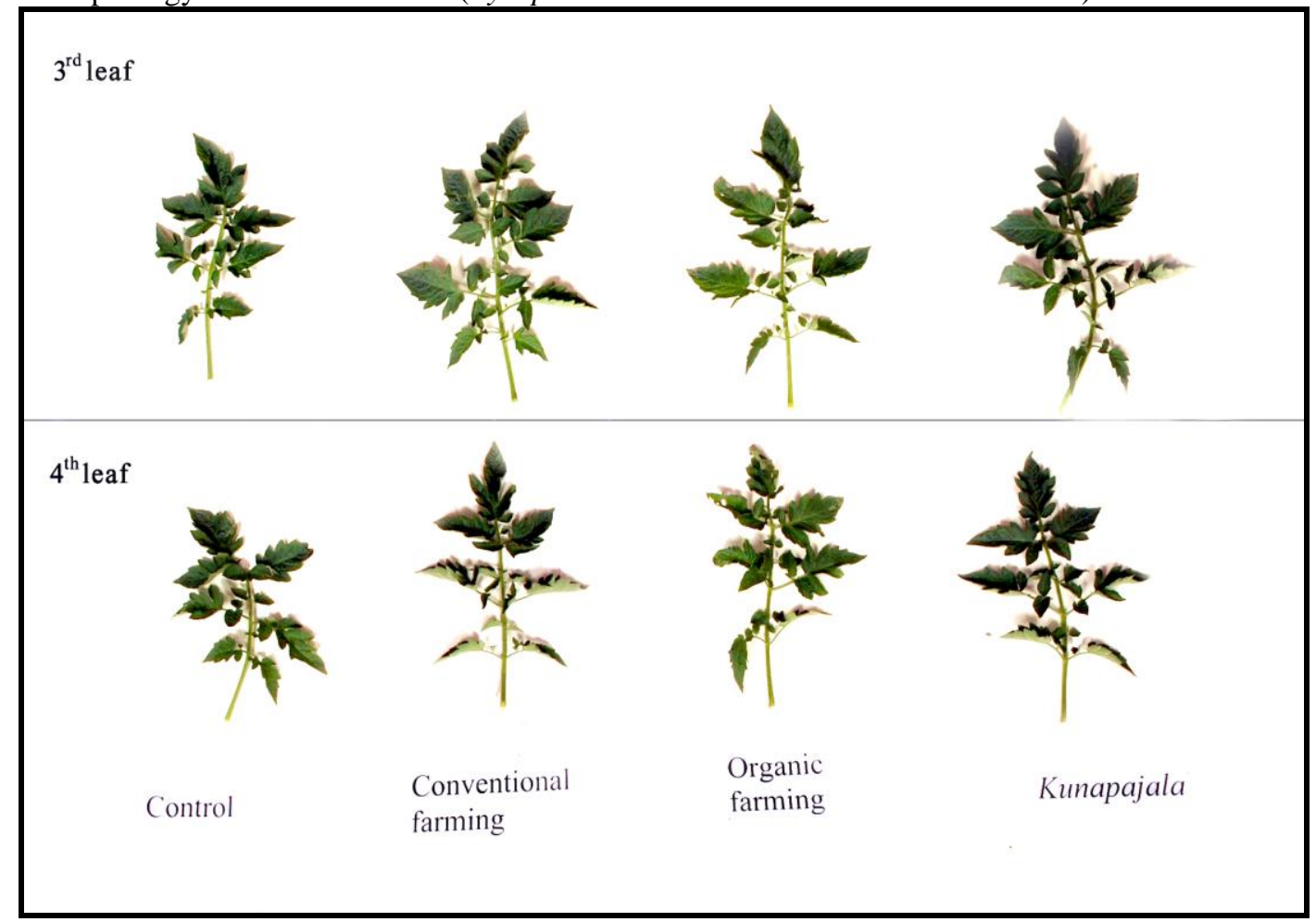

